\title{
Comparative Analysis of Different Fertilizers Effects on Maize Growth Parameters
}

\author{
KWIZERA Chantal* ${ }^{1}$, KABONEKA Salvator ${ }^{1}$, NDIHOKUBWAYO Soter ${ }^{1}$, HABONIMANA \\ Bernadette $^{1}$, NIJIMBERE Severin ${ }^{1}$, and NSENGIYUMVA Prudence ${ }^{1}$ \\ ${ }^{1}$ University of Burundi, Faculty of Agriculture and Bio Engineering,
}

Department of Environment Sciences and Technologies, B.P 2940 Bujumbura, Burundi

\begin{abstract}
Lower soil fertility was identified as a major problem affecting crop yield in Burundi, especially at Bihunge, a hill of Matongo commune Kayanza province. An experiment was therefore carried out with five treatments to assess the effective and economically affordable treatment on maze growth parameters improvement. The experimental has considered five treatments: the control (T1); Compost from maize residues + mineral adjuvant (T2); Compost from maize residues + organic adjuvant based on Calliandra calothyrsus Meisn (T3); ISABU formula for maize fertilization (T4); the maize compost + Calliandra + recommended mineral fertilization for maize (T5)), in randomized complete blocks with three replications for each. The recorded parameters were the leaves number, plant height, stem girth as well as the leaf area. After analysis with SPSS and Advanced Excel, results showed a significant difference between treatments. The treatment T4 was the most effective in improving all growth parameters than others and showed a significant difference from treatments T1, T2, and T3. However, it did not differ to treatment T5 which also significantly differed from other treatments with $P<0.05$. Treatment $T 5$ has also effectively enhanced the leaves number, plant height, stem girth, and leaf area as treatment T4, and was in the same variation range as this treatment T4. As the effectiveness of T5 was based on the combination of calliandra which has more potential in improving soil fertility and nutrient followed by better fostering of nutrients to the plant leading to better-improved plant growth, this treatment was considered as the effective and farmer accessible treatment for maize cultivation.
\end{abstract}

KEYWORDS: Growth parameters, Maize crop, Composts, Maize Fertilizer.

\section{INTRODUCTION}

Lower soil fertility is the major problem limiting agricultural productivity. It refers to a decline in soil's productivity through adverse changes in nutrients status and soil organic matter. In other words, it refers to a reduction of the soil's current and/or potential capacity to produce quantitative or qualitative goods or services ${ }^{[1]}$. Moreover, lower soil fertility is the outcome of soil degradation which is defined as a decrease in soil's actual and potential productivity owing to land misuse. Lower soil fertility is one of the greatest challenges facing mankind. Although lower soil fertility problem is from years, its extent and impact affects the human welfare and the mere fabric of mankind in general. This problem is more pronounced in Burundi, especialy in Kayanza, one of the north provinces with higher population pressure as shown in the table 1. 
International Journal of Advances in Scientific Research and Engineering (ijasre), Vol 6 (8), August -2020

Table 1. Distribution of the population by province, $2019^{[2]}$

\begin{tabular}{|c|c|c|c|c|c|}
\hline Rank & Province & Population & Rank & Province & Population \\
\hline 1 & Gitega & 725.223 & 10 & Makamba & 430,899 \\
\hline 2 & Ngozi & 660.717 & 11 & Ruyigi & 400.530 \\
\hline 3 & Muyinga & 632,409 & 12 & Rumonge & 352,026 \\
\hline 4 & Kirundo & 628.256 & 13 & Bubanza & 338,023 \\
\hline 5 & Kayanza & 585.412 & 14 & Rutana & 333.510 \\
\hline 6 & Bujumbura Mairie & 497,166 & 15 & Bururi & 313.102 \\
\hline 7 & Bujumbura Rural & 464,818 & 16 & Muramvya & 292.589 \\
\hline 8 & Cibitoke & 460.435 & 17 & Mwaro & 273,143 \\
\hline 9 & Karuzi & 436,443 & 18 & Cankuzo & 228,873 \\
\hline
\end{tabular}

Furthermore, this province is more prone to erosion, more than $400 \mathrm{t} / \mathrm{ha} / \mathrm{year}$ is lost as can be seen in the following figure $1^{[3]}$. However soil erosion is a major environmental issue which reduces soil productivity so slowly that the reduction may not be recognized until land is no longer economically suitable for growing crops ${ }^{[4]}$.

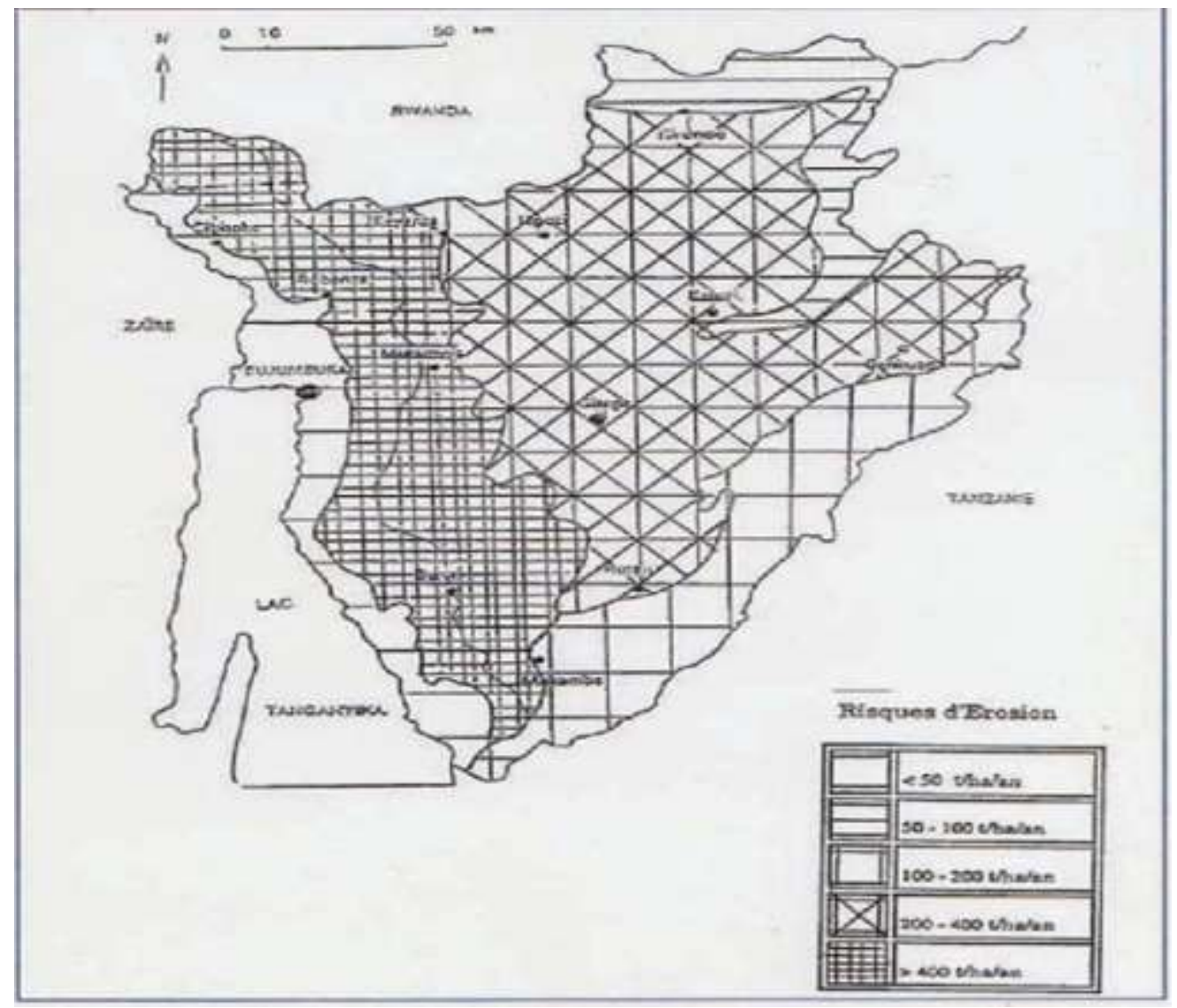

Figure 1. Figure of erosion risk in Burundi

Likewise, it was reported that erosion negatively affects crop yields ${ }^{[5-6]}$, and removes nutrients, thins the soil layer, reduces rooting depth, and damages soil structure, resulting in negative nutrient balances and lower crop yields as reported by Bossio et al. ( 2010) ${ }^{[7]}$; Zougmoré et al. ( 2009) ${ }^{[8]}$ and Zhang et al. ( 2011) ${ }^{[9]}$. Whence an enhanced lower soil fertility in this province, particularly at Bihunge (a hill of Matongo commune in kayanza province) where farmers have reduced agricultural land leading to disappeance of fallow, while livestock have been decimated during the socio-political crisis that shook Burundi country. Nowadays, many farmers cannot presumably afford recommended inputs, while the sources of organic matter at the level of rural 


\section{International Journal of Advances in Scientific Research and Engineering (ijasre), Vol 6 (8), August -2020}

Burundian households are very limited. Although several techniques for producing compost have been popularized with ditch composting method introduced by the Project of Village Cultures in High Altitude (CVHA) as the most frequently used in Burundi, there still a loss of soil sustainability whence reduced crop production leading to food insecurity ${ }^{[10]}$. The households food insecurity rate was ranged from $42.1 \%$ to $48.4 \%$ in 2016 , and $45.5 \%$ to $48.8 \%$ in 2017 . To cope with this situation, this study tested five treatments such as the Control without fertilizers (T1) ; Compost from maize residues + mineral adjuvant (T2); Compost from maize residues + organic adjuvant based on Calliandra calothyrsus Meisn (T3); ISABU formula for maize (T5), to assess the effective and economically affordable treatment which can improve the crop growth parameters for agricultural production enhancement to meet the future nutritional requirements of the people.

\section{MATERIALS AND METHODS}

\subsection{Site description and soil properties}

The experimentation site was located in Matongo Kayanza province at Bihunge, a hill with $1970 \mathrm{~m}$ of altitude, $1603.6 \mathrm{~mm}$ as average precipitation and $18.2^{\circ} \mathrm{C}$ of mean temperature and $41 \%$ for slope.

The soil texture $(0-40 \mathrm{~cm})$ is Loam, with the following chemical properties : pHwater $(5.04)$, CEC $\left(10.85 \mathrm{cmol}_{\mathrm{c}} / \mathrm{kg}\right.$ of soil), available $\mathrm{P}(5.4 \mathrm{mg} \mathrm{kg}-1)$, exchangeable $\mathrm{K}\left(0.68 \mathrm{cmol}_{\mathcal{C}} / \mathrm{kg}\right.$ of soil), exchangeable $\mathrm{Mg}\left(0.46 \mathrm{cmol}_{\mathrm{c}} / \mathrm{kg}\right.$ of soil), exchangeable Ca $\left(1.76 \mathrm{cmol}_{\mathrm{c}} / \mathrm{kg}\right.$ of soil), exchangeable $\mathrm{Al}^{3+}\left(0.76 \mathrm{cmol}_{\mathrm{c}} / \mathrm{kg}\right.$ of soil), exchangeable $\mathrm{H}^{+}\left(0.76 \mathrm{cmol}_{\mathrm{c}} / \mathrm{kg}\right.$ of soil $) .1 .33 \% \mathrm{C}$ and $0.31 \%$ N..

\subsection{Experiment design}

The experiment has considered five treatments: the Control without fertilizer (T1); Compost from maize residues + mineral adjuvant (T2); Compost from maize residues + organic adjuvant based on Calliandra calothyrsus Meisn (T3); ISABU formula (current practice of organo-mineral fertilization of maize (T4); and the maize compost + Calliandra + recommended mineral fertilization for maize (T5). These factors were designed in blocs completely rendomized with three replications for each. During the study, plant height, stem girth and leaves number were recorded, as well as the leaf area per plant. Likewise, diseases and pests were controlled through insecticide and fungicide application while all treatments had the same agricultural management practices.

\subsection{Statistical analysis}

For data analysis, advanced Excel and SPSS have been used. Comparisons between treatments were conducted through LSD (least significant difference) at $\mathrm{P}<0.05$, while figures and tables were made by using Excel.

\section{RESULTS}

\subsection{Influences of different fertilizers on Plant Height (PH)}

The results on Plant Height (PH) were summed up in the table 2. The highest PH of $70.82 \mathrm{~cm}$ was recorded for the T4 treatment in the first days $\left(18^{\text {th }}\right.$ December, 2018) with significant difference $(\mathrm{p}<0.05)$ from T1, T2 and T3 which showed plant height of 30.14 $\mathrm{cm}, 41.17 \mathrm{~cm}$ and $35.5 \mathrm{~cm}$ respectively. However this treatment did not differed from T5 which had $66.06 \mathrm{~cm}$ and also significantly differed from other treatments.

Table 2. Plant height response to different treatments

\begin{tabular}{ccccc}
\hline & $18 / 12 / 2018$ & $03 / 01 / 2019$ & $17 / 01 / 2019$ & $02 / 02 / 2019$ \\
\hline T1 & $30.14 \mathrm{a}$ & $49.54 \mathrm{a}$ & $85.82 \mathrm{a}$ & $127.98 \mathrm{a}$ \\
T2 & $41.17 \mathrm{~b}$ & $63.09 \mathrm{a}$ & $115.44 \mathrm{~b}$ & $172.84 \mathrm{~b}$ \\
T3 & $35.5 \mathrm{ab}$ & $62.18 \mathrm{a}$ & $96.43 \mathrm{ab}$ & $158.81 \mathrm{ab}$ \\
T4 & $70.82 \mathrm{c}$ & $133.16 \mathrm{~b}$ & $189.68 \mathrm{c}$ & $231.25 \mathrm{c}$ \\
T5 & $66.06 \mathrm{c}$ & $124.88 \mathrm{~b}$ & $182.73 \mathrm{c}$ & $224.41 \mathrm{c}$ \\
\hline
\end{tabular}

The same trend was observed on the $3^{\text {rd }}$ January, 2019 where T4 $(133.16 \mathrm{~cm})$ treatment got the optimum PH and did not differed from T5 $(124.88 \mathrm{~cm})$ but significantly differed from others which recorded the lowest value of $63.09 \mathrm{~cm}(\mathrm{~T} 2), 63.18 \mathrm{~cm}(\mathrm{~T} 3)$ and $49.54 \mathrm{~cm}$ (T1). For other tested dates, treatment T4 showed the maximum value of PH with $189.68 \mathrm{~cm}$ and $231.25 \mathrm{~cm}$ respectively. 
It significantly differed $(\mathrm{p}<0.05)$ from other treatments except T5. During these dates, the minimum PH was recorded for T1 treament of $85.82 \mathrm{~cm}$ and $127.98 \mathrm{~cm}$ respectively.

\subsection{Effects of different treatments on Leaves Number (LN)}

Results on leaves number for all tested date were shown in the following Figure 2. Considering this figure, the leaves number (LN) was effectively influenced by the appllied treatments. On $18^{\text {th }}$ December, 2018, the maximum LN was observed for treatment T5 (37) which did not differed from the following treatment T4 (36), but significantly differed from treatments T3 (31), T2 (29) and T1 ( 27) with $\mathrm{p}<0.05$.

\section{Leaves number}

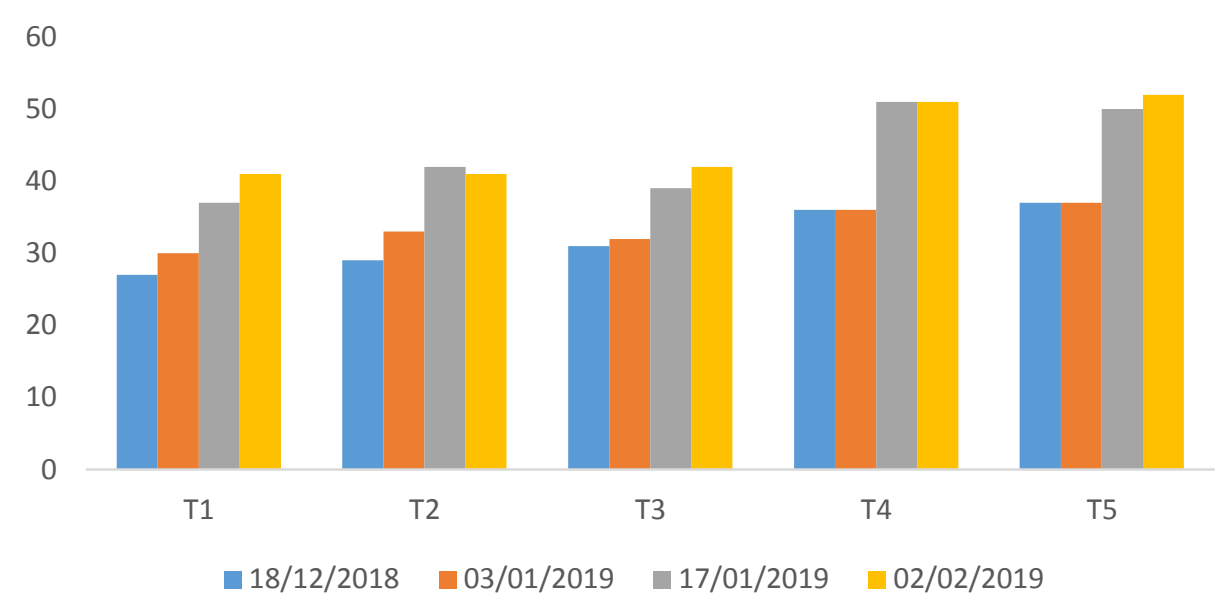

Figure 2. Leaves number (LN) response to different treatments

Similarly, on the $3^{\text {rd }}$ January 2019, the treatment T5 with 37 leaves per plant was the first having higher leaves, treatment T4 of 36 leaves per plant was the second, while treatment T1 with 30 leaves per plant was the last. On the $17^{\text {th }}$ January, the trend changes, the highest value was recorded for treatment T4 with 51 leaves, followed by treatment T5 of 50 leaves while the minimum was still recorded for treatment T1 with 37 leaves. In the last days ( $2^{\text {nd }}$ February, 2019), highest value was observed for treatment T5 (52), followed by treatment T4 (51) and minimum for treatment T1 and T2 which got the same value of 41 leaves. During all data registration date, no significance difference was observed between $\mathrm{T} 4$ and $\mathrm{T} 5$, but both treatments significantly differed from other treatments.

\subsection{Effects of different treatments on Leaf Area (LA)}

Leaf area evolution is displayed in table 3. As for the above parameters, leaf area (LA) changed with the applied treatment, and the tested date. The maximum LA in the first days $\left(18^{\text {th }}\right.$ December 2018) was observed for T4 $\left(496.07 \mathrm{~cm}^{2}\right)$, followed by T5 $\left(491.71 \mathrm{~cm}^{2}\right)$. However these treatments did not show significance difference but both significantly differed from treatments $\mathrm{T} 2$ (250.44), T3 (237.14) and T1 (180.08).

Table 3. Effects of different treatments on leaf area

\begin{tabular}{ccccc}
\hline & $18 / 12 / 2018$ & $03 / 01 / 2019$ & $17 / 01 / 2019$ & $02 / 02 / 2019$ \\
\hline T1 & $180.08 \mathrm{a}$ & $271.31 \mathrm{a}$ & $263.48 \mathrm{a}$ & $263.64 \mathrm{a}$ \\
T2 & $250.44 \mathrm{a}$ & $394.28 \mathrm{~b}$ & $399.36 \mathrm{~b}$ & $358.91 \mathrm{a}$ \\
T3 & $237.14 \mathrm{a}$ & $350.39 \mathrm{ab}$ & $333.60 \mathrm{ab}$ & $285.98 \mathrm{a}$ \\
T4 & $496.07 \mathrm{~b}$ & $811.59 \mathrm{c}$ & $800.04 \mathrm{c}$ & $789.35 \mathrm{~b}$ \\
T5 & $491.71 \mathrm{~b}$ & $745.46 \mathrm{c}$ & $765.54 \mathrm{c}$ & $750.71 \mathrm{~b}$ \\
\hline
\end{tabular}

The same LA evolution trend was observed on the $3^{\text {rd }}$ January, 2019 where the maximum LA was recorded for T4 treatment with $811.59 \mathrm{~cm}^{2}$, followed by T5 of $745.50 \mathrm{~cm}^{2}$, and minimum for the treatemnt T1 with $271.31 \mathrm{~cm}^{2}$. On the $17^{\text {th }}$ January, 2019 , as it can be seen in table 3, treatment T4 still at the first place with a maximum LA of $800.04 \mathrm{~cm}^{2}$ and did not significantly differed 


\section{International Journal of Advances in Scientific Research and Engineering (ijasre), Vol 6 (8), August -2020}

from the following treatment T5 which had $765.54 \mathrm{~cm}^{2}$, but significantly differed from T2 of $399.36 \mathrm{~cm}^{2}, \mathrm{~T} 3 \mathrm{with} 333.60 \mathrm{~cm}^{2}$ and $\mathrm{T} 1$, a treatment with a minimum value of $263.48 \mathrm{~cm}^{2}$. At the last date of data registration, the first and second highest value of LA was observed for treatments T4 $\left(789.35 \mathrm{~cm}^{2}\right)$ and T5 $(750.71)$ without significance difference. However these treaments (T4 and T5) significantly differed from T2 $\left(358.91 \mathrm{~cm}^{2}\right)$, T $3\left(285.98 \mathrm{~cm}^{2}\right)$ and $\mathrm{T} 1\left(263.64 \mathrm{~cm}^{2}\right)$, which treatments are in the same variation range.

\subsection{Effects of different fertilizers on Stem Girth (SG)}

Results on Stem girth (SG) were shown in the following Figure 3. The SG was effectively influenced by the appllied treatments. On 18th December, 2018, the maximum SG was obseved for treatment T4 $(2.08 \mathrm{~cm})$ which did not differed from the following treatment T5 $(1.95 \mathrm{~cm})$, but significantly differed from treatment T2 $(1.01 \mathrm{~cm}), \mathrm{T} 1(0.91 \mathrm{~cm})$ and T3 $(0.88 \mathrm{~cm})$.

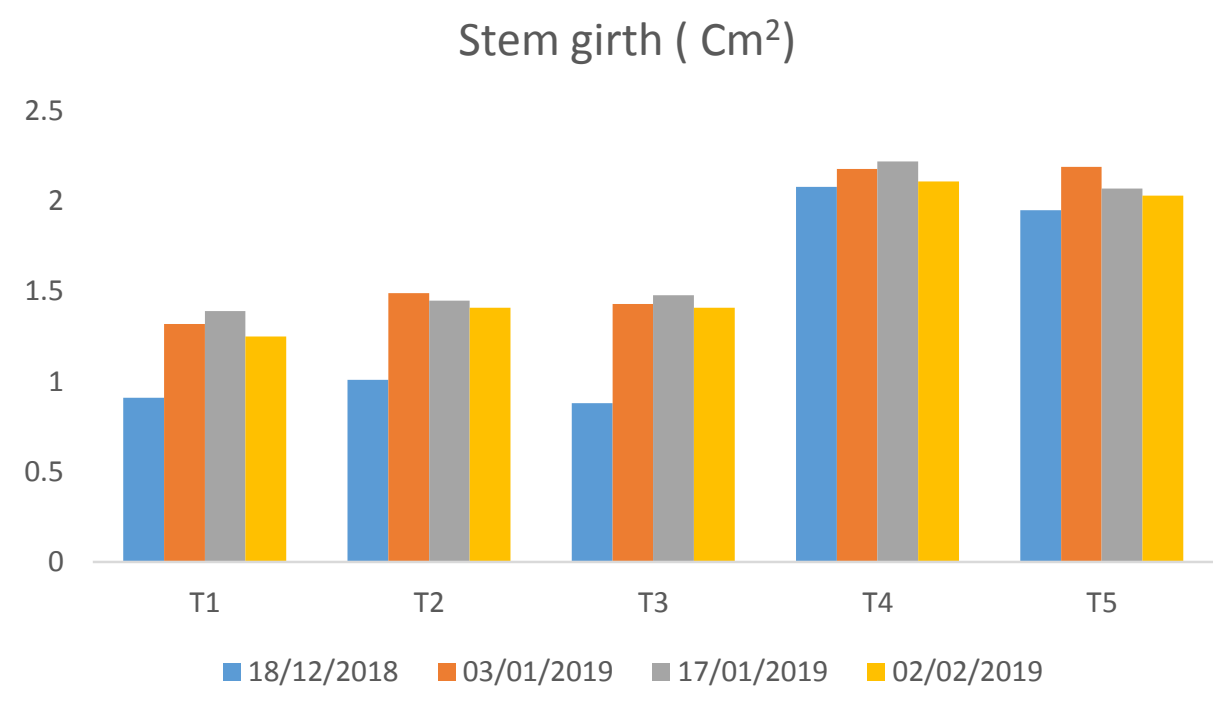

Figure 3. Stem girth as influenced by different treatments

On the $3^{\text {rd }}$ January, 2019, the trend changed, the maximum SG was observed for treatment T5 $(2.19 \mathrm{~cm})$ which did not differed from the following T4 $(2.18 \mathrm{~cm})$ but significantly differed from others which recorded the lowest value of $1.49 \mathrm{~cm}(\mathrm{~T} 2), 1.43 \mathrm{~cm}$ (T3) and $1.32 \mathrm{~cm}$ (T1). For other tested dates, treatment T4 showed the maximum value of SG with $2.22 \mathrm{~cm}$ and $2.21 \mathrm{~cm}$ respectively. It significantly differed from other treatments except treatment T5. During these dates, the minimum SG was recorded for $\mathrm{T} 1$ treament with $1.30 \mathrm{~cm}$ and $1.25 \mathrm{~cm}$ respectively. However for all tested dates, there was no significance difference between treatments $\mathrm{T} 1, \mathrm{~T} 2$ and $\mathrm{T} 3$.

\section{DISCUSSION}

Results of the study hilighted the effectiveness of treatment T4 (ISABU formula for maize fertilization) in improving crop growth parameters than others. This was due to the ability of this treatment T4 to supply nutrients that the plant need for its growth and development whence improved plant growth parameters. This treatment $\mathrm{T} 4$ showed significant difference from treatments $\mathrm{T} 1$, $\mathrm{T} 2$ and T3 with $\mathrm{p}<0.05$. However it did not differed significantly from treatment T5 for all tested parameters and each data record's date. This may be due to calliandra's potential to restore soil fertility as forefound by other researchers ${ }^{[11]}$. Moreover, it can be due to calliandra's ability to fix nitrogen from the atmosphere ${ }^{[12]}$ which has a positive effect on the nitrogen content in the soil ${ }^{[13]}$, whence an improved soil environment and nutrient followed by better fostering of nutrients to the plant leading to better improved plant growth. Furthermore, these results endorsed those of Kaho et al. (2007) ${ }^{[14]}$ who reported an improved crop maize growth parametrs with applied calliandra fallows. Likewise, the effectiveness of treatment T5 may be due to the addition of calliandra which is a suitable source of green manure as highlighted by Brewbaker, et al. (1982) ${ }^{[15]}$. Growth improvement by T5 may be achieved through calliandra's potential to regenerate soil fertility as revealed by Soerjono and Suhaendi (1981) ${ }^{[16]}$. All this could conclude the effectiveness of T5 in enhancing the growth parameters as T4 (ISABU formula) especially due to calliandra combination in this treatment $\mathrm{T} 5$ as above mentionned. 
International Journal of Advances in Scientific Research and Engineering (ijasre), Vol 6 (8), August -2020

\section{CONCLUSION}

The experimental results showed that the maize growth parameters were significantly improved by treatment T4 (ISABU formula for maize fertilization) and significantly differed from other treatments except treatment T5 (the maize compost + Calliandra + recommended mineral fertilization for maize) which was as effective as T4 due to calliandra combination in this T5. Considering that calliandra is an agroforestry shrub that farmers can get without cost, this treatment T5 can be considered as an effective and economically affordable treatment especially nowadays where 90 percent of the population still currently living on less than US\$ 2 per day ${ }^{[17]}$ and many farmers cannot presumably afford recommended inputs. Whence the study encourage farmers to use treatment T5 (the maize compost + Calliandra + recommended mineral fertilization for maize) in maize cultivation and recommand further research with these treatments on other crops especially bean which is considered as meat for burundian hoselhold.

\section{REFERENCES}

[1]Sehgal, J. and Abrol, I.P., 1994. Soil Degradation in India: Status and Impact. Oxford \& IBH, New Delhi.

[2]http://www.isteebu.bi/images/rapports/projections\%20provinciales\%20\%20\%20reajustees.pdf3.pdf

[3] http://www.fao.org/nr/water/aquastat/countries_regions/BDI/BDI-CP_fra.pdf

[4]Krauss H. A., and R.R. Allmaras. Technology masks soil erosion effects on soil productivity-a case study in Whitman County, Yashington. In Detcr,ninants of Soil Loss Tolerance. Am. Soc. Agron., Madison, Wise. 1981, volume 16 pp.61. doi:10.2134/asaspecpub45.c7

[5]Martha Bakker M., Gerard Govers, A. Robert Jones and D.A. Mark Rounsevell. The Effect of Soil Erosion on Europe's Crop Yields. ,Springer-Verlag, 2007 Volume 10, Issue 7, pp 1209-1219. DOI: 10.1007/s10021-007-9090-3

[6]Jones A.J., R. Lal, and D. R. Huggins. Soil erosion and productivity research: A regional approach. Am J of Alter Agri, 1997. Vulume (12), pp.185-192. https://doi.org/10.1017/S0889189300007554

[7]Bossio D, Geheb K, Critchley (2010) Managing water by managing land: Addressing land degradation to improve water productivity and rural livelihoods. Agric Water manage 97: 536-542. doi: http://dx.doi.org/10.1016/j.agwat.2008.12.001

[8]Zougmoré R., A. Mando, Stroosnijder (2009) Soil Nutrient and Sediment Loss as Affected By Erosion Barriers and Nutrient Source in Semi-Arid Burkina Faso. Arid Land Research and Management23: 85-101. doi: 10.1080/15324980802599142

[9]Zhang S., X. Zhang, X. Ruffman, X. Liu, J.Yang (2011) Influence of topography and land management on soil nutrient variability in Northeast China. Nutri Cycl Agroecosyst 89 (3): 427-438. https://doi.org/10.1007/s10705-010-9406-0

[10] United Nations High Commissioner for Refugees (UNHCR), Burundi Regional Refugee Response Plan, December 2018

[11]Ambayeba Muimba-Kankolongo, 2018. Common Cultivation Practices. https://www.sciencedirect.com/topics/agriculturaland-biological-sciences/calliandra-calothyrsus

[12]National Research Council (U.S.), Advisory Committee on Technology Innovations, Perhum Perhutani, Indonesia (1983): Calliandra, a Versatile Small Tree for the Humid Tropics (17.07.2020)

[13]http://www.fao.org/ag/AGP/AGPC/doc/publicat/gutt-shel/x5556e09.htm (17.11.2014)

[14] Kaho, F. Yemefack, M. Yongue-Fouateu, R.Kanmegne, J. Bilong, P. . Potentials of Calliandra calothyrsus Meissner for improving soil fertility and maize performance in the forest savannah transition zone of Cameroon. Nigerian Journal of Soil and Environmental Research. 2007 page 33-44

[15]Brewbaker, J.L., van der Beldt, R. and MacDicken, K., 1982. Nitrogen fixing tree resources: Potentials and limitations, in: Graham, P.H. and S.C. Harris (eds.). Biological nitrogen fixation technology for tropical Agriculture, CIAT, Cali, Columbia pp. 413-425.

[16]Soerjono, R. and Suhaendi, H. 1981. The prospect of Calliandra plantation in Indonesia. Paper presented for discussion concerning Calliandra between National Academy of Sciences (NAS) - USA and Indonesia, held on 14th May 1981

in Jakarta.

[17]Report of World Food and Agriculture Organisation of United Nations, 2015. Socio-economic context and role of agriculture 